\title{
The Infection of Soybean Leaves by Phakopsora pachyrhizi during Conditions of Discontinuous Wetness
}

\author{
Gleiber Quintão Furtado ${ }^{1}$, Sylvia Raquel Gomes Moraes $^{2}$, Sílvio André Meirelles Alves ${ }^{3}$, Lilian Amorim ${ }^{2}$ and \\ NELSON SIDNEI MASSOLA JÚNIOR ${ }^{2}$ \\ Authors' addresses: ${ }^{1}$ Departamento de Fitopatologia, Universidade Federal de Viçosa, Av. P.H. Rolfs s/n, CEP 36570-000, \\ Vicosa, MG, Brazil; 'Departamento de Fitopatologia e Nematologia, Escola Superior de Agricultura "Luiz de Queiroz", \\ Universidade de Sao Paulo, Caixa Postal 09, CEP 13418-900, Piracicaba, SP, Brazil; ${ }^{3}$ Estação Experimental de Fruticultura \\ Temperada, Embrapa Uva e Vinho, Rod. BR 285, Km 115, CEP 95200-000, Vacaria, RS, Brazil (correspondence to N. S. \\ Massola Jr. E-mail: nmassola@esalq.usp.br)
}

Received March 22, 2010; accepted August 9, 2010

Keywords: soybean rust, uredospores, wetness interruption, infection

\begin{abstract}
The ability of Phakopsora pachyrhizi to cause infection under conditions of discontinuous wetness was investigated. In in vitro experiments, droplets of a uredospore suspension were deposited onto the surface of polystyrene. After an initial wetting period of either 1, 2 or $4 \mathrm{~h}$, the drops were dried for different time intervals and then the wetness was restored for 11,10 or $8 \mathrm{~h}$. Germination and appressorium formation were evaluated. In in vivo experiments, soybean plants were inoculated with a uredospore suspension. Leaf wetness was interrupted for 1,3 or $6 \mathrm{~h}$ after initial wetting periods of 1,2 or $4 \mathrm{~h}$. Then, the wetting was re-established for 11,10 or 8 h, respectively. Rust severity was evaluated 14 days after inoculation. The germination of the spores and the formation of the appressoria on the soybean leaves after different periods of wetness were also quantified in vivo by scanning electron microscopy. P. pachyrhizi showed a high infective capacity during short periods of time. An interruption of wetness after $1 \mathrm{~h}$ caused average reductions in germination from 56 to $75 \%$ and in appressorium formation from 84 to $96 \%$. Rust severity was lower in all of the in vivo treatments with discontinuous wetness when compared to the control plants. Rust severity was zero when the interruption of wetness occurred $4 \mathrm{~h}$ after the initial wetting. Wetting interruptions after 1 and $2 \mathrm{~h}$ reduced the average rust severity by 83 and $77 \%$, respectively. The germination of the uredospores on the soybean leaves occurred after $2 \mathrm{~h}$ of wetness, with a maximum germination appearing after $4 \mathrm{~h}$ of wetness. Wetness interruption affected mainly the spores that had initiated the germination.
\end{abstract}

\section{Introduction}

Soon after its introduction from Paraguay in 2001, soybean rust (SR) caused severe crop epidemics in Brazil.
In 2002 and 2003, the disease had already spread into 60 and $90 \%$ of the soybean crop areas, respectively. Losses due to this disease in 2003 exceeded \$1 billion and in 2004 over \$2 billion (Yorinori et al. 2005). Crop damage in the Eastern hemisphere was also reported at around $10-40 \%$ in Thailand, $10-90 \%$ in India, 10 $50 \%$ in China, 23-90\% in Taiwan and 40\% in Japan (Sinclair and Hartman 1999).

The infection process of Phakopsora pachyrhizi H. \& P. Sydow is composed of several distinct stages: uredospore adhesion onto the surface of the host, germination, appressorium formation, direct penetration through the cuticle, invasion and growth of the hyphae into the host tissue (Marchetti et al. 1975; Bonde et al. 1976; Melching et al. 1979; Koch et al. 1983; Koch and Hoppe 1988). Host penetration occurs directly in the lumen of epidermal cells. Less often, the process begins in the space between adjacent cells, and subsequently, the fungus enters into one of these cells (Bonde et al. 1976).

Infection success of most pathogenic fungi depends on minimum leaf wetness and varies with the temperature (Huber and Gillespie 1992). Phakopsora pachyrhizi was reported to cause infection after a minimum period of $6 \mathrm{~h}$ of leaf wetness at temperatures between 15 and $25^{\circ} \mathrm{C}$ (Marchetti et al. 1976). Despite the fact that the infection process of $P$. pachyrhizi has been widely investigated, there is still no information on infection development during discontinuous leaf wetness. Information on the development and biology of $P$. pachyrhizi infection may aid in developing new control methods and may be useful for the validation of disease simulation models. Our objective was to understand the infection process of P.pachyrhizi and the development of soybean rust under periods of interrupted leaf wetness. 


\begin{abstract}
Material and Methods
Obtaining uredospores

Uredospores of $P$. pachyrhizi were obtained from naturally rusted soybean plants growing in Piracicaba, Sao Paulo, Brazil and were multiplied through successive inoculations on soybean plants cv. BRS 154. The plants were inoculated with a suspension of $10^{5}$ uredospores $/ \mathrm{mL}$ of distilled water + Tween 20 at $0.05 \%$ and kept in a growth chamber (Model E7; Conviron, Winnipeg, $\mathrm{MB}$, Canada) at $23^{\circ} \mathrm{C}$. During the first $24 \mathrm{~h}$, the plants remained under humid and dark conditions. The growth chamber conditions were then adjusted to a 12-h photoperiod of light. The spores were collected periodically every 2 days, 10 days after inoculation. Spores were collected by gently agitating the infected leaflets onto a Petri dish and stored according to Furtado et al. (2008).
\end{abstract}

\section{The effect of in vitro wetness interruption}

A spore suspension containing $10^{5}$ uredospores $/ \mathrm{mL}$ was prepared, and $30 \mu \mathrm{L}$ droplets of this suspension were laid onto polystyrene Petri dishes measuring $90 \mathrm{~mm}$ in diameter. These plates were placed individually into plastic boxes $\left(121 \mathrm{~cm}^{2}\right.$ by $3.2 \mathrm{~cm}$ deep) that were lined with three sheets of filter paper moistened with distilled water. Incubation was performed inside an incubator at $23^{\circ} \mathrm{C}$ in the dark. The treatments consisted of $12 \mathrm{~h}$ of discontinuous leaf wetness. After the initial wetting periods of 1,2 or $4 \mathrm{~h}$, the wetting was halted for 3 or $6 \mathrm{~h}$. After these dry periods, the wetness was restored for 11,10 or $8 \mathrm{~h}$, respectively, by adding $30 \mu \mathrm{L}$ of sterile distilled water onto the area that contained the droplets. The control plates were kept under continuous wet periods of 1, 2, 4 and $12 \mathrm{~h}$. To remove the wetness in order to obtain the dry periods, the plates were placed under continuous air flow conditions in a laminar flow hood. At the end of each treatment, $15 \mu \mathrm{L}$ of lactoglycerol was added to each droplet to stop germination. The drops were then covered with a glass cover slip. The percentage of germination and appressorium formation was evaluated by counting 100 uredospores arbitrarily per replicate under an optical microscope at a $100 \times$ magnification. The experiment was performed with four replicates per treatment. Each replication consisted of a Petri dish containing three droplets of the spore suspension.

\section{The effect of in vivo wetness interruption}

Potted plants of soybean cv. BRS 154 in growth stage V1 (Fehr and Caviness 1977) were inoculated with a suspension of $10^{5}$ uredospores/mL. The spore suspension was sprayed onto a pair of opposite leaves to run-off and then the plants were kept in a moist chamber. At the moment of inoculation, the uredospores showed $52 \%$ germination that was measured previously on $2 \%$ water agar.

The experimental treatments included a combination of initial wet periods ranging from 1,2 to $4 \mathrm{~h}$ that were interrupted for dry intervals of 1,3 or $6 \mathrm{~h}$.
A final wetting period of 11,10 or $8 \mathrm{~h}$, for the respective 1,2 and $4 \mathrm{~h}$ of initial wet treatments, was then applied to obtain at least $12 \mathrm{~h}$ of discontinuous wetness. The wet periods and the dry periods were maintained, respectively, through the presence and absence of the moist chamber. The dry periods started when the leaves were completely dry as determined by visual examination, which took 20-30 min for all treatments. After the dry periods, the wetness was reintroduced by spraying water onto the adaxial surface of leaves until wetted completely avoiding run-off. In this experiment, the control plants were submitted to $12 \mathrm{~h}$ of continuous wetness.

The plants remained at a temperature of $23^{\circ} \mathrm{C}$, which is considered to be favourable for the occurrence of the disease (Marchetti et al. 1976), and a 12-h photoperiod of light inside the incubator (Model E7; Conviron, Canada).

The evaluation of infection was performed by quantifying the severity of the disease, which was conducted 14 days after the inoculation by means of digital photography. The programs PAINT SHOP PRo 7 (JASC Software Inc., Eden Prairie, MN, USA) and Image Tool (UTHSCSA, San Antonio, TX, USA) were used according to Alves et al. 2005. The experiment was performed with 16 replications, and each replication consisted of a leaf that was inoculated.

\section{Assessing the infection process through Scanning Electron Microscopy}

To observe the development of the infectious process during different periods of wetness, soybean leaves were inoculated and observed using Scanning Electron Microscopy (SEM). For this purpose, the leaves of the soybean cV. BRS 154 that were at the V1 developmental stage were detached, washed in running water, air dried and maintained in plastic boxes $\left(121 \mathrm{~cm}^{2}\right.$ by $3.2 \mathrm{~cm}$ deep). The boxes were lined with three sheets of filter paper moistened with $15 \mathrm{~mL}$ of distilled water to create a saturated environment. Inoculation was performed through the deposition of two $30 \mu \mathrm{L}$ droplets of spore suspension $\left(10^{5}\right.$ uredospores $\left./ \mathrm{mL}\right)$ onto each leaf. The boxes containing the leaves were then covered and placed in an incubator at $23^{\circ} \mathrm{C}$ in darkness. Samples from the inoculated regions of the leaves were removed after 1, 2, 4, 7 and $12 \mathrm{~h}$ of continuous wetness and were then fixed for $12 \mathrm{~h}$ in osmium vapour (Kitajima and Leite 1999). After fixation, the samples were dehydrated for $24 \mathrm{~h}$ in a hermetically sealed container containing silica gel. These samples were affixed to aluminium supports ('stubs') with a double-coated carbon tape and were then sputter-coated with gold with a MED 110 sputtering machine (Balzers Union Ltd., Balzers, Liechtenstein) at $50 \mathrm{~mA}$ for $180 \mathrm{~s}$. Observations of the leaves were made using a Zeiss DSM 940A Scanning Electron Microscope (Carl Zeiss, Jena, Germany).

One hundred uredospores per sample were evaluated, and the percentages of germination and appressorium formation were calculated. The experiment was 
performed with four repetitions, and each inoculated leaf was considered as one repetition.

\section{Data Analysis}

There were some treatments or repetitions with zero as average, which led to no equal variances according to the $t$-test (Ruxton 2006). Thus, data were not tested statistically using ANOVA and comparison of means. Therefore, mean and standard error were calculated for each treatment using the software sAS (SAS Institute Inc., Cary, NC, USA).

All experiments were conducted twice, and the results represent the average of both experiments, as there was no significant difference between them according to the $t$-test.

\section{Results}

The uredospores of $P$. pachyrhizi showed a $52 \%$ germination rate and a $27 \%$ appressorium formation proportion in vitro after $12 \mathrm{~h}$ of incubation at $23^{\circ} \mathrm{C}$ under continuous wetness. Similar germination and appressorium formation rates were obtained with an initial wetness of only 2 or $4 \mathrm{~h}$ from both the treatments that included additional wetting after a dry period and those that did not (Fig. 1). These results show the rapid formation of infective structures by $P$. pachyrhizi.
The interruption of the wetness period reduced the germination and the appressorium formation only after short periods of initial wetness. When the interruption of the wetness occurred after $1 \mathrm{~h}$, germination was reduced, on average, by $64 \%$ (Fig. 1a). The formation of appressoria was more affected when the interruption occurred after $1 \mathrm{~h}$ of initial wetting, resulting in reductions ranging from 84 to $96 \%$. Interruptions in the wetness conditions after $2 \mathrm{~h}$ reduced the formation of appressoria from 63 to $84 \%$ (Fig. 1b). When the interruption of the initial wetness occurred after $1 \mathrm{~h}$, longer dry periods led to higher reductions in both the germination rate and appressorium formation. In this case, dry periods of $6 \mathrm{~h}$ caused a reduction in germination and appressorium formation of $75 \%$ and $93 \%$, respectively, compared with $56 \%$ and $84 \%$ in dry periods of $3 \mathrm{~h}$, respectively.

The severity of the SR infection in the soybean leaves was reduced by the interruption of the wet period after 1, 2 and $4 \mathrm{~h}$ of initial wetting. When the inoculated plants were subjected to $12 \mathrm{~h}$ of continuous leaf wetness, the severity of the SR infection was $30 \%$. The treatments with an initial wetting of 1 and $2 \mathrm{~h}$ followed by an interruption of 1 or $3 \mathrm{~h}$ were equivalent and had a reduced severity of the SR infection that was between 78 and $70 \%$. However, the reduction in the severity of the SR infection was more drastic when the interruption of the 2 -h wetness period was $6 \mathrm{~h}$. In
Fig. 1 Interruption effect of in vitro wetness in the germination (a) and appressorium formation (b) of Phakopsora pachyrhizi uredospores. Bars represent the standard error
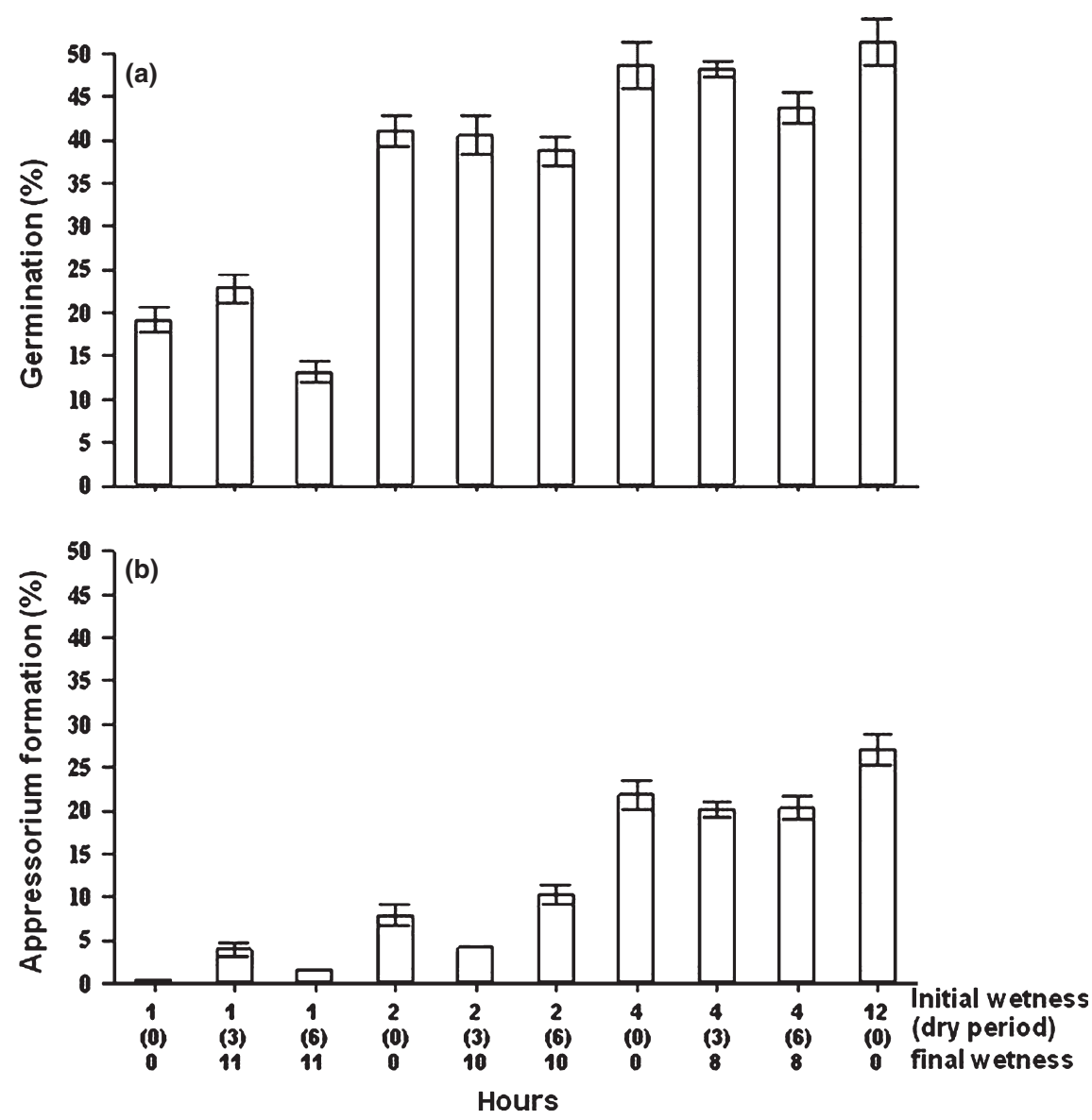
this case, the severity of the SR infection was reduced by $92 \%$. After $4 \mathrm{~h}$ of initial wetting, any period of interruption in the wetness resulted in the absence of SR infection (Fig. 2).

Studies with SEM showed that there was no germination of the uredospores $1 \mathrm{~h}$ after inoculation (h a.i.) (Figs 3a and 4a). The germination values obtained at $2 \mathrm{~h}$ a.i. $(7 \%)$ was lower from those with $4(31 \%), 7$ $(35 \%)$ and $12(34 \%)$ h a.i.; however, no differences were evident among the latter treatments. The germination of the spores peaked after $4 \mathrm{~h}$ of leaf wetness. Figure $4 \mathrm{~b}$ shows the spores during this time interval. The formation of appressoria began $4 \mathrm{~h}$ a.i. $(6.5 \%)$ and increased over the time to reach $18.5 \%$ at $12 \mathrm{~h}$ a.i (Fig. 3b). Figs. $4 \mathrm{c}$ and d show images of the appressorium formation at $7 \mathrm{~h}$ a.i. and $12 \mathrm{~h}$ a.i, respectively.

\section{Discussion}

This study showed that the uredospores of P. pachyrhizi germinate and form infective structures during wet periods of less than $4 \mathrm{~h}$ at $23^{\circ} \mathrm{C}$. According to Marchetti et al. (1976), the spores of P. pachyrhizi require $6 \mathrm{~h}$ to germinate between 15 and $25^{\circ} \mathrm{C}$.

The particular speed of the infective process of $P$. pachyrhizi explains, in part, the aggressive nature of SR. However, the results also showed a reduction in the infective capacity of the spores when wetness was interrupted, indicating the intolerance of these spores to dry periods after the beginning of the germination process. The interruption of leaf wetness after $4 \mathrm{~h}$ of initial wetness eliminated the disease for all of dry intervals tested. When wetness was interrupted after 1 or $2 \mathrm{~h}$, a reduction in the infective process was observed with severity levels much lower than the control treatment with continuous wetness.

Reductions in the infective capacity under discontinuous wetness were also observed in other pathosystems for fungi that cause rust and other diseases including Puccinia recondita f.sp. tritici (Stuckey and Zadoks 1989; De Vallavieille-Pope et al. 1995), P. striiformis on wheat (De Vallavieille-Pope et al. 1995); Cercospora kikuchii in soybean (Schuh 1993); Coccomyces hiemalis in cherry (Eisensmith et al. 1982) and Botrytis squamo$s a$ in onion (Alderman et al. 1985).

Assessments of the influence of the dry period for different host-pathogen interactions have shown mixed results. Arauz and Sutton (1990) observed that for the pathosystem of Botryosphaeria obtusa and apple, a dry period of $1 \mathrm{~h}$ after $12 \mathrm{~h}$ of initial wetting compromised the infectious process in the same manner that interruptions of 2, 3 or $4 \mathrm{~h}$ did. However, on carrot leaves, Cercospora carotae was favoured by 3 -h dry periods
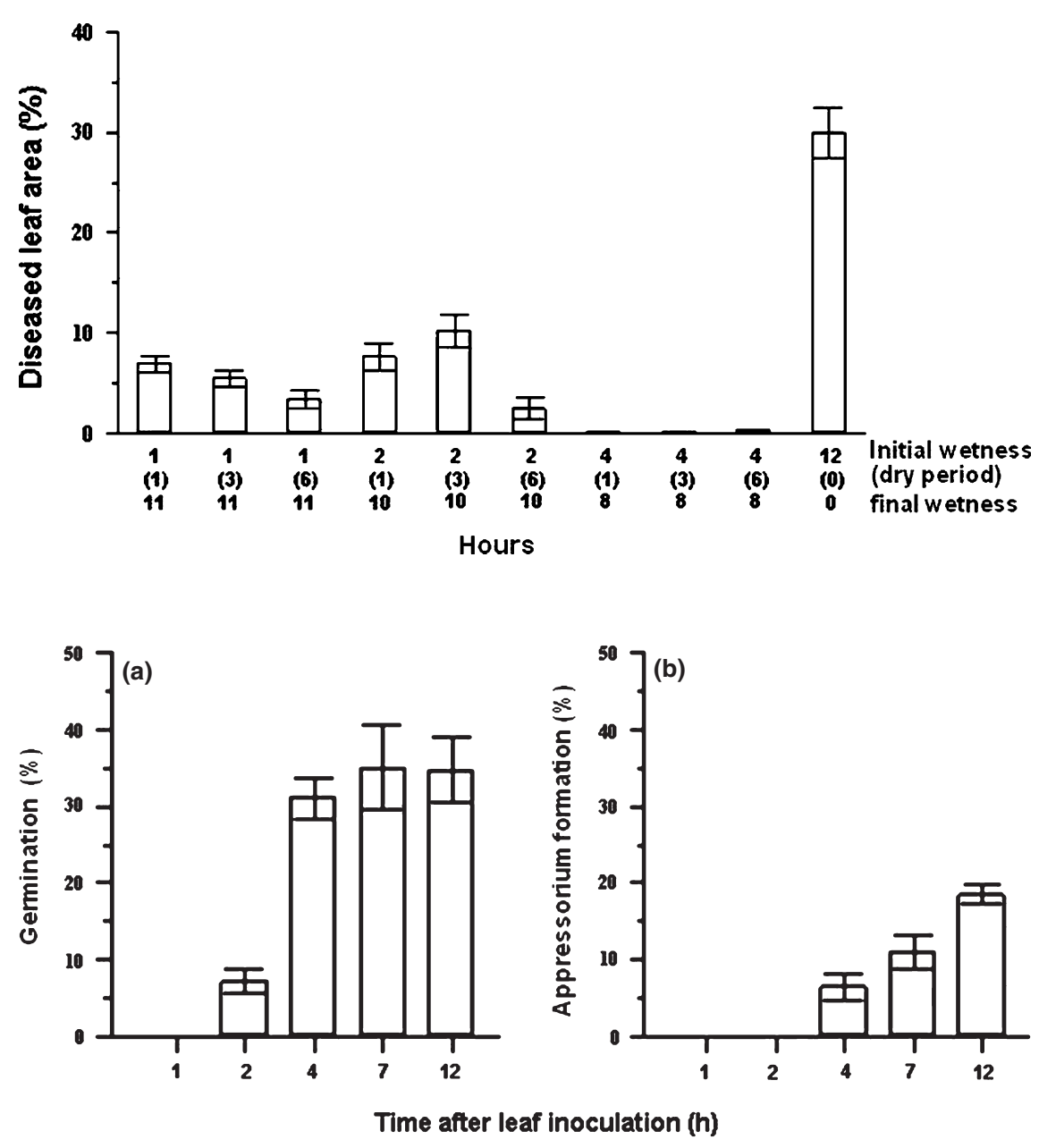

Fig. 2 Interruption effect of wetness in the severity of soybean rust in the soybean cv. BRS 154 leaves. Bars represent the standard error
Fig. 3 Germination (a) and appressorium formation (b) of Phakopsora pachyrhizi on soybean cv. BRS154 leaves, as a function of time. Bars represent the standard error 
Fig. 4 Scanning Electron Microscopy images of Phakopsora pachyrhizi pre-penetration in the leaves of the soybean cv. BRS 154. (a) Uredospores $1 \mathrm{~h}$ after inoculation, (b) Uredospores $4 \mathrm{~h}$ after inoculation, (c) Uredospores germinated with (arrowhead) and without (arrow) appressorium $7 \mathrm{~h}$ after inoculation, (d) Detail of appressorium at $12 \mathrm{~h}$ after inoculation (arrowhead). Note that the content of the spore migrated to the appressorium. Bar $=20 \mu \mathrm{m}$
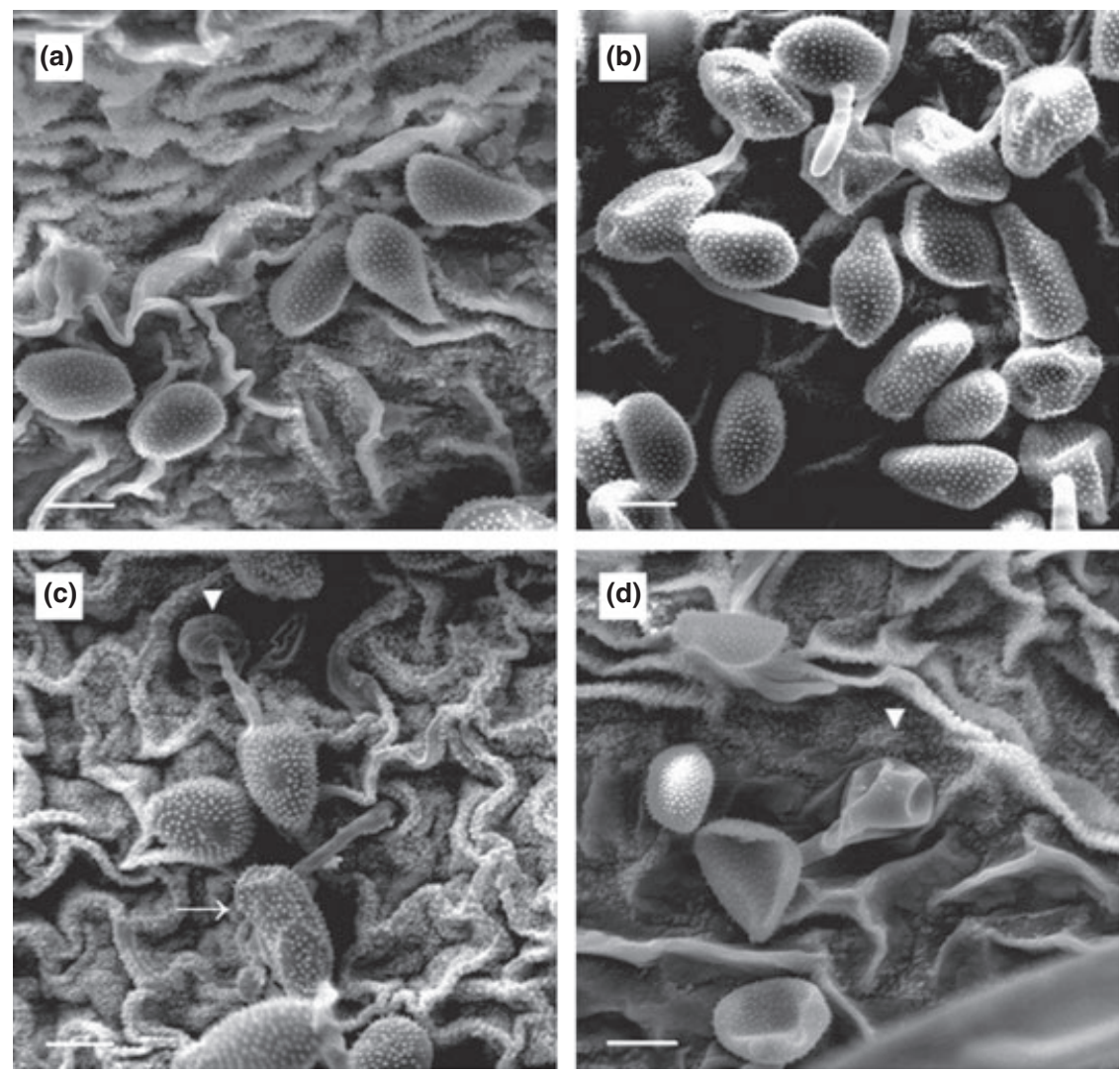

between the initial wetting $(24 \mathrm{~h})$ and final wetting $(12 \mathrm{~h})$, with a larger number of lesions per plant in this particular treatment compared to the corresponding continuous period of wetness (Carisse and Kushalappa 1992). However, for SR, our studies showed that this stimulating effect on germination after wetness interruption and subsequent additional re-wetting has not been observed.

Examination of leaves inoculated using SEM revealed that after $4 \mathrm{~h}$ a.i. the rate of germination of the spores was already at a maximum. On the other hand, few appressoria had been formed. Thus, the high fragility of the germ tubes and the probable absence of already established infections help to explain the absence of SR when wetness was interrupted for $4 \mathrm{~h}$ a.i. These observations are in agreement with the results obtained for Puccinia recondita f.sp. tritici and P. striiformis in wheat (De Vallavieille-Pope et al. 1995). Infections of both of these rusts were affected similarly by dry periods after the germination of the uredospores and before the formation of the sub-stomatal vesicle. According to these authors, when the initial wetting was less than the minimum period required for an infection, the germinated uredospores died and only those that had not germinated were able to germinate during the second wetting.

In our results, however, when the wetness was interrupted after 1 and $2 \mathrm{~h}$ a.i. (when only a few spores had enough time to germinate), good success in the infectious process was observed. Moreover, it was expected that these treatments obtained higher disease severity than observed, particularly after the 1 -h initial wetness period in which there was no germination of the spores. Thus, it is speculated that the interruption of the leaf wetness also irreversibly affected the spores that were in the germination process but the germ tube had not yet emerged.

Arauz and Sutton (1989) observed that the nongerminated conidia of Botryosphaeria obtusa were sensitive to the interruption of wetness, with a reduction of over $60 \%$ in viability after $20 \mathrm{~min}$ at the beginning of the dry period. With Venturia inaequalis, the causal agent of apple scab, the viability of its non-germinated conidia was not reduced during exposure to dry intervals higher than or equal to $24 \mathrm{~h}$, regardless of the temperature and relative humidity. As for the conidia that had germinated, there was a decrease of $20 \%$ after the first $15 \mathrm{~min}$ of the dry interval and a further decrease of 10-30\% after $96 \mathrm{~h}$ (Becker and Burr 1994).

For P. recondita f.sp. tritici, De Vallavieille-Pope et al. (1995) found that the appressoria with complete penetration into the wheat were able to continue the infectious process after the dry period. For P. pachyrhizi, it was demonstrated in this study that the appressoria that formed with $4 \mathrm{~h}$ of wetness did not contribute to the occurrence of SR in soybean leaves. It is possible that the time was insufficient for the formation of the hyphal penetration that would ensure the fungal infection.

It is interesting to report that the pathogens show variable responses in relation to the wetness period. 
The work of Bashi and Rotem (1974) illustrates the ability of some pathogenic fungi to cause epidemics in semi-arid habitats where the periods of wetness are discontinuous or short. According to these authors, in tomato, Stemphylium botryosum f.sp. lycopersici infected as successfully under discontinuous wetness as it did under long periods of continuous wetness, even when the dry period occurred after the germination of the conidia. On potato leaves, the same authors observed that the strategy adopted by Phytophthora infestans and Alternaria porri f.sp. solani involved the rapid penetration to compensate for the sensitivity of its spores to desiccation. According to Jacome and Schuh (1992), in addition to having germ tubes that are capable of surviving in dry intervals between wet periods, Mycosphaerella fijiensis var. difformis, the causal agent of black sigatoka in bananas, has the ability to infect when the wet period is short or absent as long there is high humidity. According to the papers mentioned earlier, fungi that infect under interrupted wetness have two basic strategies for survival: 1) rapid germination and penetration into the host or 2) high survivability of the germinated spores.

The results from the present study may support the development of predictive models that use climate data to model the occurrence of SR.

A possible future experiment could test if soybeans that are grown at a less dense spacing provide higher crop aeration that subsequently would reduce the infectiveness of $P$. pachyrhizi. In a less dense cropping system, the formation of free water on the leaves might be stopped or the established wetness might be lost more rapidly. The severity of SR could be lower under these cropping conditions.

\section{References}

Alderman SC, Lacy ML, Everts KL. (1985) Influence of interruptions of dew period on numbers of lesion produced on onion by Botrytis squamosa. Phytopathology 75:808-810.

Alves SAM, Carneiro LC, Furtado GQ, Bergamim Filho A. (2005) Método preciso para quantificação de ferrugem asiática da soja. Fitopatol Bras 30S:132.

Arauz LF, Sutton TB. (1989) Influence of temperature and moisture on germination of ascopores and conidia of Botryosphaeria obtusa. Phytopathology 79:449-444.

Arauz LF, Sutton TB. (1990) Effect of interrupted wetness periods on spore germination on apple infection by Botryosphaeria obtusa. Phytopathology 80:1218-1220.

Bashi E, Rotem J. (1974) Adaptation of four pathogens to semi-arid habitats as conditioned by penetration rate and germinating spore survival. Phytopathology 64:1035-1039.

Becker CM, Burr TJ. (1994) Discontinuous wetting and survival of conidia of Venturia inaequalis on apple leaves. Phytopathology 84:372-378.
Bonde MR, Melching JS, Bromfield KR. (1976) Histology on the suspect-pathogen relationship between Glycine max and Phakopsora pachyrhizi. Phytopathology 66:1290-1294.

Carisse O, Kushalappa AC. (1992) Influence of interrupted wet periods, relative humidity, and temperature on infection of carrots by Cercospora carotae. Phytopathology 82:602-606.

De Vallavieille-Pope C, Huber L, Leconte M, Goyeau H. (1995) Comparative effects of temperature and interrupted wet periods on germination, penetration, and infection of Puccinia recondita $\mathrm{f} s \mathrm{~s}$. tritici and $P$. Striformis on wheat seedlings. Phytopathology 85:409-415.

Eisensmith SP, Jones AL, Cress CE. (1982) Effects of interrupted wet periods on infection of sour cherry by Coccomyces hiemalis. Phytopathology 72:680-682.

Fehr WR, Caviness CE. (1977) Special Report 80. Ames, IA, Iowa State University Press.

Furtado GQ, Alves SAM, Czermainski ABC, Massola Júnior NS. (2008) Preservation of Phakopsora pachyrhizi uredospores. J Phytopathol 156:62-64.

Huber L, Gillespie TJ. (1992) Modeling leaf wetness in relation to plant disease epidemiology. Annu Rev Phytopathol 30:553-577.

Jacome LH, Schuh W. (1992) Effects of leaf wetness duration and temperature on development of black sigatoka disease on banana infected by Mycosphaerella fijiensis var. difformis. Phytopathology 82:515-520.

Kitajima EW, Leite B. (1999) Curso introdutório de microscopia eletrônica de varredura, 2 edn. Piracicaba, SP, Brasil, ESALQ/USP.

Koch E, Hoppe HH. (1988) Development of infection structures by the direct-penetrating soybean rust fungus (Phakopsora pachyrhizi Syd.) on artificial membranes. J Phytopathol 22:232-244.

Koch E, Ebrahim-Nesbat F, Hoppe HH. (1983) Light and electron microscopic studies on the development of soybean rust (Phakopsora pachyrhizi Syd.) in susceptible soybean leaves. Phytopathol Z 106:302-320.

Marchetti MA, Uecker FA, Bromfield KR. (1975) Uredial development of Phakopsora pachyrhizi in soybean. Phytopathology 65:822-823.

Marchetti MA, Melching JS, Bromfield KR. (1976) The effects of temperature and dew period on germination and infection by uredospores of Phakopsora pachyrhizi. Phytopathology 66:464463.

Melching JS, Bromfield KR, Kingsolver CH. (1979) Infection, colonization, and uredospore production on Wayne soybean by four culture of Phakopsora pachyrhizi, the cause of soybean rust. Phytopathology 69:1262-1265.

Ruxton GD. (2006) The unequal variance $t$-test is an underused alternative to Student's $t$-test and the Mann-Whitney $U$ test. Behav Ecol 17:688-690.

Schuh W. (1993) Influence of interrupted dew periods, relative humidity, and light on disease severity and infections caused by Cercospora kikuchii on soybean. Phytopathology 83:109-113.

Sinclair JB, Hartman GL. (1999) Soybean rust. in: Hartman GL, Sinclair JB, Rupe JC. (eds) Compedium of Soybean Diseases. St Paul, APS Press, pp 3-4.

Stuckey RE, Zadoks JC. (1989) Effect of interrupted leaf wetness periods on pustule development of Puccinia recondita $\mathrm{f}$ sp. tritici on wheat. Neth J Plant Pathol 95:175-185.

Yorinori JT, Paiva WM, Frederick RD, Costamilan LM, Bertagnolli PF, Hartman GE, Godoy CV, Nunes J Jr. (2005) Epidemics of soybean rust (Phakopsora pachyrhizi) in Brazil and Paraguay from 2001 to 2003. Plant Dis 89:675-677. 